\title{
Analysis Absorption of English Learning Materials in E-Learning
}

\author{
A.A. Gede Raka Wahyu Brahma ${ }^{1 *}$, Gede Dana Pramitha² \\ 1,2,3 STMIK STIKOM Indonesia, Bali, Indonesia
}

\section{A R T I C L E I N F O}

Article history:

Received March 02, 2021

Revised March 04, 2021

Accepted April 28, 2021

Available online May 25, 2021

Kata Kunci:

E-learning, Bahasa Inggris,

Penyerapan

Keywords:

E-learning, English, Absorption

DOI:

http://dx.doi.org/10.23887/jpbi.v9 i1.32588

\section{A B S T R A C T}

Communication science is very important in supporting the activities of the world community. Nowadays one must be able to speak English to compete. Some students stated that the absorption and understanding of English vocabulary on technology materials and sentence structure were limited. This has an impact on students' low English skills. The purpose of this study is to analyze the absorption of English learning materials in E-learning. This type of research is qualitative. Data collection techniques used in this study were interviews, Documentation Studies. The types and sources of data in this study are primary and secondary data. The technique used to analyze the data is descriptive qualitative and quantitative. The result of the research is that after learning English is done by E-learning, it is easier for students to understand English learning because E-learning can allow students to learn anywhere and students can understand English learning materials easily. This research implies that the use of E-learning in learning English will improve students' understanding of learning so that it impacts increasing student learning outcomes.

This is an open-access article under the CC BY-SA license. Copyright (C) 2021 by Author. Published by Universitas Pendidikan Ganesha.

\begin{abstract}
A B S T R A K mahasiswa menyatakan bahwa penyerapan dan pemahaman kosakata bahasa Inggris pada materi teknologi dan susunan kalimat yang terbatas. Hal ini berdampak pada kemampuan bahasa inggris pada mahasiswa yang rendah. Tujuan penelitian ini yaitu menganalisis penyerapan materi pembelajaran bahasa inggris dalam E-learning. Jenis penelitian ini yaitu kualitatif. Teknik pengumpulan data yang digunakan dalam elitian ini adalah wawancara, Studi Dokumentasi. Jenis dan sumber data pada penelitian ini yaitu data primer dan sekunder. Teknik yang digunakan untuk menganalisis data adalah deskriptif kualitatif dan kuantitatif. Hasil penelitian yaitu
disimpulkan bahwa setelah pembelajaran bahasa Inggris dilakukan secara Elearning, siswa lebih mudah memahami pembelajaran bahasa inggris karena Elearning dapat membuat siswa dapat belajar dimana saja dan siswa dapat memahami materi pembelajaran Bahasa Inggris dengan mudah. Implikasi penelitian ini yaitu penggunaan E-elarning dalam pembelajaran bahasa Inggris akan meningkatkan pemahaman mahasiswa dalam belajar sehingga berdampak pada hasil belajar mahasiswa yang meningkat.
\end{abstract}


and in real-time (Simamora, 2020; I. Yusuf \& Widyaningsih, 2020). The E-learning system does not have access restrictions; this allows lectures to be carried out in more time. Whenever and wherever, as long as there is an internet network, students can access this system. E-learning activities can be classified according to the time of the learning implementation, namely Synchronous and Asynchronous E-learning (Eze et al., 2018; Mpungose, 2021). Synchronous E-learning is where teachers and students engage in learning activities simultaneously, such as video conferences, chats, and real-time videos (Kiernan, 2020; Simamora, 2020). There are asynchronous learning activities at different times, such as sending/providing teaching materials via email and file sharing (ElMagboub et al., 2016; Mpungose, 2021). Teachers are currently required to use E-learning in learning to still run smoothly, especially in learning English.

Communicating using English is an ability that is needed today (Naghdipour, 2021; Sirivedin et al., 2018). The science of communication is essential in supporting the activities of the world community. Mastering communication, especially foreign languages (English), is one of the skills that students must have to know the development of science globally (Chen \& Hsu, 2020; Sun et al., 2021). Good English skills can be used in the world of work later. Schools have indeed taught good communication skills to universities (Amin \& Sundari, 2020; Effendi M., 2016). One of the information technology-based tertiary institutions provides English lectures, namely STMIK STIKOM Indonesia. Students are required to take this course from the fourth semester. However, today's problem is that there are still many students who have a limited understanding of vocabulary. The initial interviews with several students revealed that the absorption and understanding of vocabulary were limited for technology materials and sentence structure in learning. This has an impact on students' low English skills.

Previous research also stated that learning English is a complex subject for students (Kurniawati, 2019; Megawati, 2016). There are still many students who have difficulty communicating using English. Other research findings also state that there are still many students who have low proficiency in speaking English, both in pronunciation, grammar (grammar), and vocabulary (vocabulary) (Dwi et al., 2013; Liyana \& Kurniawan, 2019; Surjono, 2016). This is because students think that speaking in English is very difficult, so students are afraid to make mistakes. In addition, in the learning process, students also have difficulty conveying thoughts and questions in English using various spoken languages correctly and adequately. In addition, students' interest and ability in speaking English are still shallow. This can be seen from the scores obtained by students in the learning process (Kurniawati, 2019; Rosmiati, 2019). Then, some students are still confused about what they should say when speaking verbally. Thus, this has an impact on the teaching and learning process to be less conducive.

Learning English using the E-learning system should make it easier for students to learn. This is because the E-learning system will make it easier for students to learn anywhere and anytime (Daniel \& Kamioka, 2017; Shetu et al., 2021). The findings of previous research also stated that E-learning would make it easier for students to study anywhere (Fatmawati, 2019; Mpungose, 2021). The findings of previous studies also state that E-learning will motivate students in learning (Amalia \& Brata, 2018; Nácher et al, 2021). There is no study regarding the absorption of English learning materials in E-learning. The purpose of this study is to analyze the absorption of English learning materials in E-learning.

\section{METHOD}

The research was carried out by analyzing the implementation of a questionnaire survey of students' perceptions about the subject matter of e-learning English 3 at STMIK STIKOM Indonesia and other things to get input on the improvement of the material. This research is divided into several steps which can be seen in Figure 1.

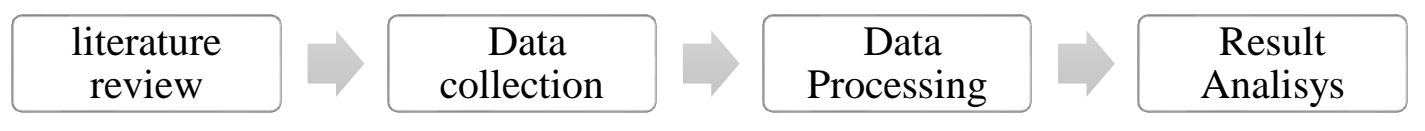

Figure 1. Research Flow

The data collection techniques used in this study are interview, Documentation Study. The interview is a data collection technique from the results of question and answers questionnaires with STMIK STIKOM Indonesia students. Documentation Study is a data collection technique by searching for data in related documents, books, the internet, or journals related to this research. The supporting reference used in this research is in the form of textbooks related to the English language material of several journals related to research. At the data collection stage, the types and sources of data used are as follows. Primary data is data obtained directly from the results of questionnaires for STMIK STIKOM Indonesia students who have taken English lesson 3. Secondary data is data 
obtained from literature studies such as data from previous research and other data obtained from books and scientific journals. The technique used to analyze the data is descriptive qualitative and quantitative.

\section{RESULT AND DISCUSSION}

Result

From the questionnaire data to 123 students who gave the most stringent responses to questions taken from the study program plan (RPS) in the ongoing semester to students who had taken English 3 lessons in semester 4 using a scale of 1 to 5 of each question was obtained answer as follows:

Table 1. Questionnaire data are given to students

\begin{tabular}{llllrrr}
\hline No & \multicolumn{1}{c}{ Material } & \multicolumn{1}{c}{$\mathbf{1}$} & $\mathbf{2}$ & $\mathbf{3}$ & $\mathbf{4}$ & $\mathbf{5}$ \\
\hline 1 & Use of Classroom & $1,6 \%$ & $18 \%$ & $34,4 \%$ & $36,1 \%$ & $9,8 \%$ \\
2 & English for computer & $0 \%$ & $9 \%$ & $36,9 \%$ & $42,6 \%$ & $11,5 \%$ \\
3 & Software dan hardware & $0,8 \%$ & $11,4 \%$ & $36,6 \%$ & $39 \%$ & $12,2 \%$ \\
4 & Reading Activity & $0 \%$ & $8,1 \%$ & $37,4 \%$ & $40,7 \%$ & $13,8 \%$ \\
5 & English for Advertisement & $0 \%$ & $9,8 \%$ & $32 \%$ & $44,3 \%$ & $13,9 \%$ \\
6 & Future Trend Technology & $0,8 \%$ & $8,2 \%$ & $39,3 \%$ & $36,9 \%$ & $14,8 \%$ \\
7 & My Gadget & $0 \%$ & $7,4 \%$ & $36,1 \%$ & $42,6 \%$ & $13,9 \%$ \\
8 & Popular Software & $0,8 \%$ & $7,3 \%$ & $36,6 \%$ & $39 \%$ & $16,3 \%$ \\
9 & Scope of internet & $0,8 \%$ & $8,9 \%$ & $38,2 \%$ & $38,2 \%$ & $13,8 \%$ \\
10 & English for World wide web & $0 \%$ & $8,1 \%$ & $36,6 \%$ & $38,2 \%$ & $17,1 \%$ \\
11 & Safety online & $0 \%$ & $8,9 \%$ & $37,4 \%$ & $37,4 \%$ & $16,3 \%$ \\
\hline
\end{tabular}

From the results above, it is known that the understanding for scale 1 is $4.8 \%$ on average; for scale 2 , an average of $9.7 \%$ is obtained, for scale 3 is obtained an average of $36.7 \%$, for scale 4 , the average is obtained 40 $\%$, and a scale of 5 obtained $13.9 \%$. If the scale means for a scale of 1 (wrong), a scale of 2 (bad), a scale of 3 (good), a scale of 4 (good), and a scale of 5 (excellent). Based on the results of the data analysis, it can be concluded that students' understanding is still lacking in learning English given by the lecturer during teaching. However, after E-learning does learning, students are easier to understand learning English. Several factors, namely as follows, cause this.

\section{Discussion}

First, E-learning can enable students to learn English anywhere. Online learning allows students to access lessons whenever they want to find it easier to learn (Hanum, 2013; Hignasari \& Supriadi, 2020; Shetu et al., 2021). It is by the characteristics of E-learning, namely utilizing electronic and internet technology services so that it is easy to access (Dhika et al., 2019; Satyawan et al., 2021). In addition, E-learning provides independent teaching materials that can be accessed by students and lecturers anytime and anywhere (Nácher, Badenes-Ribera, Torrijos, Ballesteros, et al., 2021; Ran \& Jinglu, 2020). It makes E-learning able to provide flexibility in choosing a time and place to study for students. E-learning will also allow students to learn independently to increase student learning success (Amalia \& Brata, 2018; Tere et al., 2020).

Second, E-learning allows students to understand English subject matter quickly. Because students are given the freedom to learn and review their learning again, making it easier for them to understand the subject matter presented in E-learning (Ambarita, 2021; Shaik Alavudeen et al., 2021). In addition, E-learning also provides teaching materials or visual, audio, and audiovisual learning media to facilitate students in learning (Kuzmanović et al., 2019). Learning by student learning styles will also make it easier for students to absorb learning information (Awaludin et al., 2020; Solehana et al., 2019). E-learning can also support the implementation of the learning process to increase student absorption of the material taught by the lecturer. In addition, E-learning can also increase the active participation of students (Logan et al., 2021; Wu \& Plakhtii, 2021). E-learning utilizes the lesson schedule, curriculum, learning progress results so that they can be viewed at any time. In addition, E- 
learning also provides cost efficiency, physical facilities, and facilities for learning (Kurtz et al., 2014; Putra \& Sudarti, 2015).

The findings of previous studies also state that E-learning is effectively used in learning (Ja'ashan, 2020; Mitra et al., 2021). Other research findings also state that E-learning makes it easier for students to learn independently (Amiti, 2020; Ardini et al., 2020). It can be concluded that E-learning will facilitate students in learning. This research implies that the use of e-learning in learning English will increase students' understanding of learning so that it impacts increasing student learning outcomes.

\section{CONCLUSION}

It can be concluded that after learning English is done by E-learning, it is easier for students to understand English learning because E-learning can make students able to study anywhere, and students can understand English learning materials easily. It is recommended for lecturers to use E-learning so that students can learn English independently.

\section{REFERENCES}

Amalia, F., \& Brata, A. H. (2018). Analisis Tingkat Penerimaan Sistem E-Learning menggunakan Blog Gratis sebagai Alternatif Media Pembelajaran pada Guru. Jurnal Teknologi Informasi Dan Ilmu Komputer, 5(3), 335. https://doi.org/10.25126/jtiik.201853640

Ambarita, E. (2021). Belajar Dari Rumah (Bdr) Menggunakan Padlet Alternatif E-Learning Pada Masa Pandemi Covid-19 (Studi Kasus Di Sman 56 Jakarta). JIRA: Jurnal Inovasi Dan Riset Akademik, 2(1), 30-36. https://doi.org/10.47387/jira.v2i1.70

Amin, F., \& Sundari, H. (2020). EFL Students ' Preferences on Digital Platforms during Emergency Remote Teaching: Video Conference, LMS, or Messenger Application? Studies in English Language and Education, 7(2), 362-378. https://doi.org/10.24815/siele.v7i2.16929

Amiti, F. (2020). Synchronous and asynchronous E-learning. European Journal of Open Education and ELearning Studies, 5(2), 60-70. https://doi.org/10.46827/ejoe.v5i2.3313

Ardini, L., Iswara, U. S., \& Retnani, E. D. (2020). Efektivitas Penggunaan E-Learning Sebagai Media Pembelajaran Saat Pandemi Covid 19. JKBM:Jurnal Konsep Bisnis Dan Manajemen, 7(1), 72-81. https://doi.org/10.31289/jkbm.v7i1.4333

Aris, B., Ardian, A., \& Ferry, M. (2019). Pengembangan Media Pembelajaran Berbasis E-Learning Pada SMK di Pontianak. Jurnal Nasional Komputasi Dan Teknologi Informasi (JNKTI), 2(2), 133. https://doi.org/10.32672/jnkti.v2i2.1556

Awaludin, Wibawa, \& Winarsih. (2020). Integral Calculus Learning Using Problem Based Learning Model Assisted by Hypermedia-Based E-Book. Jurnal Pendidikan Indonesia, 9(2). https://doi.org/10.23887/jpiundiksha.v9i2.23106

Batubara, H. H., \& Batubara, D. S. (2020). Penggunaan Video Tutorial untuk Mendukung Pembelajaran Daring di Masa Pandemi Virus Corona. Jurnal Madrasah Ibtidaiyah, 5(2). https://doi.org/http://dx.doi.org/10. 31602/muallimuna.v5i2.2950.

Bayles, J., Peterson, A. D., Pitts, S. J., Bian, H., Burkholder, S., Hegde, A. V., \& Stage, V. C. (2021). Food-Based Science, Technology, Engineering, Arts, and Mathematics (STEAM) Learning Activities May Reduce Decline in Preschoolers' Skin Carotenoid Status. Journal of Nutrition Education and Behavior, 53(4). https://doi.org/10.1016/j.jneb.2020.10.017

Chen, Y.-L., \& Hsu, C.-C. (2020). Self-regulated mobile game-based English learning in a virtual reality environment. Computers \& Education, 154. https://doi.org/10.1016/j.compedu.2020.103910

Dahalan, H. M., \& Hussain, R. M. R. (2010). Development of Web-Based Assessment in Teaching and Learning Management System (e-ATLMS). Procedia - Social and Behavioral Sciences, 9. https://doi.org/10.1016/j.sbspro.2010.12.144

Daniel, K. N., \& Kamioka, E. (2017). Detection of Learner's Concentration in Distance Learning System with Multiple Biological Information. Journal of Computer and Communications, 05(04), 1-15. https://doi.org/10.4236/jcc.2017.54001

Dhika, H., Destiawati, F., Sonny, M., \& Surajiyo. (2019). Study of the use and application of the moodle e-learning platform in high school. Journal of Physics: Conference Series, 1175, 012219. https://doi.org/10.1088/17426596/1175/1/012219

Dwi, N. M. L., Suwatra, I. I. W., \& Rasana, I. D. P. R. (2013). Pengaruh Model Pembelajaran Kooperatif Tipe Inside Outside Circle Terhadap Keterampilan Berbicara Bahasa Inggris Kelas IV SD Gugus X Kecamatan 
Buleleng. Mimbar PGSD Undiksha, 1(1). https://doi.org/10.23887/jjpgsd.v1i1.746

Effendi M. (2016). Penerapan Lesson Study dalam Meningkatkan Kemampuan Mengajar Guru Bahasa Inggris pada Madrasah Tsanawiyah Negeri Model Sorong. Journal of Islamic Education, 1(2). https://doi.org/10.30984/j.v1i2.430

El-Magboub, A., Haworth, I. S., Sutch, B. T., \& Romero, R. M. (2016). Evaluation of in-class and online discussion meetings in a biopharmaceutics problem-based learning class. Currents in Pharmacy Teaching and Learning, 8(6), 811-820. https://doi.org/10.1016/j.cptl.2016.08.021

Eze, S. C., Chinedu-Eze, V. C., \& Bello, A. O. (2018). The utilization of e-learning facilities in the educational delivery system of Nigeria: a study of M-University. International Journal of Educational Technology in Higher Education, 15(1). https://doi.org/10.1186/s41239-018-0116-Z

Fatmawati, S. (2019). Efektivitas Forum Diskusi Pada E-Learning Berbasis Moodle Untuk Meningkatkan Partisipasi Belajar. Refleksi Edukatika: Jurnal Ilmiah Kependidikan, 9(2). https://doi.org/10.24176/re.v9i2.3379

Hanum, N. S. (2013). Keefektifan E-learning Sebagai Media Pembelajaran (Studi Evaluasi Model Pembelajaran E-learning SMK Telkom Sandhy Putra Purwokerto. Jurnal Pendidikan Vokasi, 3, 90-102. https://doi.org/10.21831/jpv.v3i1.1584

Hignasari, L. V., \& Supriadi, M. (2020). Pengembangan E-Learning dengan Metode Self Assessment Untuk Meningkatkan Hasil Belajar Matematika Mahasiswa Universitas Mahendradatta. Jurnal Kependidikan, 6(2). https://doi.org/10.33394/jk.v6i2.2476

Ja' ashan, M. (2020). The Challenges and Prospects of Using E-learning among EFL Students in Bisha University. Arab World English Journal, 11(1), 124-137. https://doi.org/10.24093/awej/vol11no1.11

Kiernan, J. E. (2020). Pedagogical commentary: Teaching through a pandemic. Social Sciences \& Humanities Open, 2(1), 100071. https://doi.org/10.1016/j.ssaho.2020.100071

Kivunja, C. (2015). Unpacking the Information, Media, and Technology Skills Domain of the New Learning Paradigm. International Journal of Higher Education, 4(1). https://doi.org/10.5430/ijhe.v4n1p166

Kurniawati, D. (2019). Keefektifan Pengajaran Kosakata Bahasa Inggris Pada Anak Sekolah Dasar Dengan Menggunakan Flash Card. Jurnal Pendidikan Dan Pembelajaran Dasar, 2(2), 59. https://doi.org/10.37484/manajemen_pelayanan_hotel.v2i2.40

Kurtz, G., Tsimerman, A., \& Steiner, O. (2014). The Flipped Classroom Answer to Future Learning? European Journal of Open, Distance and E-Learning, 17(2). https://doi.org/10.2478/eurodl-2014-0027

Kuzmanović, M., Andjelković-Labrović, J., \& Nikodijević, A. (2019). Designing e-learning environment based on student preferences: Conjoint analysis approach. International Journal of Cognitive Research in Science Engineering and Education, 7(3), 37-47. https://doi.org/10.5937/IJCRSEE1903037K

Liao, S., Hong, J.-C., Wen, M.-H., Pan, Y.-C., \& Wu, Y.-. (2018). Applying Technology Acceptance Model (TAM) to explore Users' Behavioral Intention to Adopt a Performance Assessment System for E-book Production. EURASIA Journal of Mathematics, Science and Technology Education, 14(10). https://doi.org/10.29333/ejmste/93575

Liyana, A., \& Kurniawan, M. (2019). Speaking Pyramid sebagai Media Pembelajaran Kosa Kata Bahasa Inggris Anak Usia 5-6 Tahun. Jurnal Obsesi: Journal of Early Childhood Education, 3(1). https://doi.org/10.31004/obsesi.v3i1.178

Logan, R. M., Johnson, C. E., \& Worsham, J. W. (2021). Development of an E-learning Module to Facilitate Student Learning and Outcomes. Teaching and Learning in Nursing, 16(2), 139-142. https://doi.org/10.1016/j.teln.2020.10.007

Madleňák, R. et al. (2015). Designing a Social Network to Support E-learning Activities at the Department of Communications, University of Žilina. Procedia - Social and Behavioral Sciences, 176, 103-110. https://doi.org/10.1016/j.sbspro.2015.01.449

Megawati. (2016). Kesulitan Mahasiswa Dalam Mencapai Pembelajaran Bahasa Inggris Secara Efektif. Jurnal Pedagogia, 5(2). https://doi.org/10.21070/pedagogia.v5i2.246

Mitra, N. K., Aung, H. H., Kumari, M., Perera, J., Sivakumar, A., Singh, A., \& Nadarajah, V. D. (2021). Improving the learning process in anatomy practical sessions of chiropractic program using e-learning tool. Translational Research in Anatomy, 23, 100100. https://doi.org/10.1016/j.tria.2020.100100

Mpungose, C. B. (2021). Lecturers' reflections on the use of Zoom video conferencing technology for e-learning at a South African university in the context of coronavirus. African Identities. https://doi.org/10.1080/14725843.2021.1902268

Nácher, M. J., Badenes-Ribera, L., Torrijos, C., \& Ballesteros, M. A. (2021). The effectiveness of the GoKoan elearning platform in improving university students' academic performance. Studies in Educational Evaluation, 70. https://doi.org/10.1016/j.stueduc.2021.101026

Nácher, M. J., Badenes-Ribera, L., Torrijos, C., Ballesteros, M. A., \& Cebadera, E. (2021). The effectiveness of the GoKoan e-learning platform in improving university students' academic performance. Studies in 
Educational Evaluation, 70. https://doi.org/10.1016/j.stueduc.2021.101026

Naghdipour, B. (2021). English writing pedagogy at the crossroads: The case of Oman. Journal of Second Language Writing, 52. https://doi.org/10.1016/j.jslw.2021.100815

Putra, P. D. A., \& Sudarti. (2015). Pengembangan Sistem E-Learning untuk Meningkatkan Keterampilan Berpikir Kritis Mahasiswa Pendidikan Fisika. Jurnal Fisika Indonesia, 19(55), 45-48. https://doi.org/10.22146/jfi.24373

Ran, W., \& Jinglu, L. (2020). The Design and Development of Digital Books for E-learning. 2020 4th International Conference on Artificial Intelligence and Virtual Reality, 51-55. https://doi.org/10.1145/3439133.3439140

Rosmiati, M. (2019). Animasi Interaktif Sebagai Media Pembelajaran Bahasa Inggris Menggunakan Metode ADDIE. Paradigma: Jurnal Komputer Dan Informatika Univiersitas Bina Sarana Informatika, 21(2). https://doi.org/10.31294/p.v21i2.6019

Satyawan, I. M., Wahjoedi, W., \& Swadesi, I. K. I. (2021). The Effectiveness of Online Learning Through Undiksha E-Learning During the Covid-19 Pandemic. Journal Education Technology, 5(2). https://doi.org/10.23887/jet.v5i2.32364

Shaik Alavudeen, S., Easwaran, V., Iqbal Mir, J., Shahrani, S. M., Ali Aseeri, A., Abdullah Khan, N., Mohammed Almodeer, A., \& Abdullah Asiri, A. (2021). The influence of COVID-19 related psychological and demographic variables on the effectiveness of e-learning among health care students in the southern region of Saudi Arabia. Saudi Pharmaceutical Journal. https://doi.org/10.1016/j.jsps.2021.05.009

Shetu, S. F., Rahman, M. M., Ahmed, A., Mahin, M. F., Akib, M. A. U., \& Saifuzzaman, M. (2021). Impactful elearning framework: A new hybrid form of education. Current Research in Behavioral Sciences, 2(April), 100038. https://doi.org/10.1016/j.crbeha.2021.100038

Sidhu, R., \& Gage, W. H. (2021). Enhancing the odds of adopting e-learning or community-focused experiential learning as a teaching practice amongst university faculty. Heliyon, 7(4). https://doi.org/10.1016/j.heliyon.2021.e06704

Simamora, R. M. (2020). The Challenges of Online Learning during the COVID-19 Pandemic: An Essay Analysis of Performing Arts Education Students. Studies in Learning and Teaching, 1(2), 86-103. https://doi.org/10.46627/silet.v1i2.38

Sirivedin, P., Soopunyo, W., Srisuantang, S., \& Wongsothorn, A. (2018). Effects of Facebook usage on English learning behavior of Thai English teachers. Kasetsart Journal of Social Sciences, 39(2). https://doi.org/10.1016/j.kjss.2018.03.007

Solehana, L., Asrori, A., \& Usman, A. (2019). The Development of E-Learning Teaching Material Based on Edmodo on Basic Competencies of National Integration at Class X of Senior High School. Journal of Education, Teaching And Learning, 4(2). https://doi.org/10.26737/jetl.v4i2.1914

Sun, T., Wang, C., Lambert, R. G., \& Liu, L. (2021). Relationship between second language English writing selfefficacy and achievement: A meta-regression analysis. Journal of Second Language Writing, 53. https://doi.org/10.1016/j.jslw.2021.100817

Surjono, J. (2016). Pengembangan Multimedia Pembelajaran Bahasa Inggris Untuk Pembelajaran Teks Recount Di Mtsn II Yogyakarta. Jurnal Inovasi Teknologi Pendidikan, 3(1), 25-39. https://doi.org/10.21831/tp.v3i1.8287

Tere, T., Bayu Seta, H., Nizar Hidayanto, A., \& Abidin, Z. (2020). Variables Affecting E-Learning Services Quality in Indonesian Higher Education: Students' Perspectives. Journal of Information Technology Education: Research, 19, 259-286. https://doi.org/10.28945/4489

Wu, W., \& Plakhtii, A. (2021). E-Learning Based on Cloud Computing. International Journal of Emerging Technologies in Learning (IJET), 16(10), 4. https://doi.org/10.3991/ijet.v16i10.18579

Yulia, H. (2020). Online Learning to Prevent the Spread of Pandemic Corona Virus in Indonesia. ETERNAL (English Teaching Journal), 11(1). https://doi.org/10.26877/eternal.v11i1.6068

Yusuf, I., \& Widyaningsih, S. W. (2020). Implementing e-learning-based virtual laboratory media to students' metacognitive skills. International Journal of Emerging Technologies in Learning, 15(5). https://doi.org/10.3991/ijet.v15i05.12029 